\title{
Oropharyngeal (p16-Negative) Cancer cN2b TNM Finding v8
}

National Cancer Institute

\section{Source}

National Cancer Institute. Oropharyngeal (p16-Negative) Cancer cN2b TNM Finding v8. NCl Thesaurus. Code C132949.

Oropharyngeal (p16-negative) cancer with metastases in multiple ipsilateral lymph nodes, none larger than $6 \mathrm{~cm}$ in greatest dimension and ENE(-). (from AJCC 8th Ed.) 